\title{
RECOGNIZING LEAN SIX SIGMA SOFTWARE PROJECT MANAGER BY FUZZY METHODOLOGY IN SOFTWARE INDUSTRY
}

\author{
Dr. Chandrakanth G Pujari, Mr. Deepak K R, Mr. Balaram M \\ Professor and Head of Department of MCA, Dr. Ambedkar Institute of Technology \\ Assistant Professor, BMS College of Commerce and Management \\ Assistant Professor, BMS College of Commerce and Management
}

\begin{abstract}
The main objective of this research is to design a structure for Identifying Lean Six Sigma Software Manager among software professionals by Fuzzy Sets. Researchers investigated that the software management of six sigma software projects and software management's dedication are important for the deterrence of failure of them. Because the problem of identification of lean six sigma manager has several and differing conditions, this is MCDM (Multiple criteria Decision Making) software problem. Geometric structure of trapezoidal interval FAHP (Fuzzy Analytical Hierarchy Process) technology. This is several times used techniques, is applied for software company manager identification, membership functions of fuzzy sets. It provides additional degrees of freedom that make it possible to directly model uncertainties. There is no study about the selection of lean six sigma software manager in suitable literature. Software Company is one of the most important sectors for jobs all over the world. Some software companies are contacted and studied their software processes carefully. In Lean Six Sigma Software manager identification process, there are multiple criteria to consider and many candidates. In order to put those software development criteria in numerical presentation and ranking, Fuzzy Analytical Hierarchy Process (FAHP) is a widely used Multi Criteria Decision Making (MCDM) tool. In this article, the planned criteria are Software Project Development Team Leadership-PC1, Software Project Development Sectoral Expertise-PC2, Personal and Software Project Development Environmental Analysis CapabilityPC3,Software Training andEducation-PC4.
\end{abstract}

Key Words: Software Manager Selection; Fuzzy Analytical Hierarchy Process; Lean six sigma; Multi criteria Decision Making ; Software Development Processes

\section{INTRODUCTION}

The main objective of this research is to design a structure for identifying Lean Six Sigma software Manager by Fuzzy Sets. The geometric structure of trapezoidal interval (FAHP) technology is used for an software Firm manager identification. The important key software resource of a new software Industry is human resources [3][4]. Software developer make changes in today's worldwide software development and economy. The efficiency of Lean six sigma software manager can depend almost all every serious software development processes in a software industry, since lean six sigma software projects concentrate on the problematic software development processes, software development bottlenecks, and the software development processes to be improved. The researcher has not given more importance to identification of a lean six sigma software development manager. If the identification of a software manager fails it will yields heavy expenditure and waste of time and software resources. Because of various interrupts, it is very difficult to find a perfect techniques for software professional recruitment and selection. Lean Six Sigma concept started to be used in year 2000 as an integration of Six Sigma and Lean six sigma two concepts are used independently[5][6].

Reputed Organization Toyota Japan Company. Lean six sigma manufacturing is called production of Toyota Company Method, which has continuous search to remove waste called Muda (Muda is Japanese word)[1][2], the active participation of software developer to improvement of software development processes, to minimize software project inventory level, maximize software productivity, to avoid software project late deliveries, to solve the software development problem of bottleneck software project development operations, cover a onetime software production, the satisfied software customers, smooth flow of a software production or software service system like a river, etc.. lean six sigma software development as "a way to specify value, line up value-creating actions in the best sequence, conduct those activities without interruption whenever someone requests them, and perform them more and more effectively. In short, lean thinking is lean because it provides a way to do more and more with less and less - less human effort, less human equipment, less time, and less space - while coming closer and closer to providing software customers with exactly what they want." 


\section{PRINCIPLES FOR IDENTIFYING LEAN SIX SIGMA SOFTWARE MANAGER}

This research study present software serious success factors of six sigma software projects and apply a survey in India with some respondents. That Software Manager, software project management and six sigma techniques used for the selected problem are very important for the success of six sigma software projects. Evaluated the software Information System Qualification software professional's identification of software development project process. After applying the questionnaire, respondent software managers formal top 3 ranked employing principle by using the below principle:

1. Software Project Development Grade Point Average (SPD-GPA).

2. Software Project Development Problemsolving skills.

3. Written and oral communications skills.

4. Software Project Development Leadership through extra-curricular activities.

5. Self-confidence of Software Project Development and poise during the interview process.

6. Software Project Development Experience or full-time Internship or work experience.

7. Software Project Development Skills or Technical Skills

Intimated Software Project Development have confidence in to hire highly qualified employees, because they may achieve carrier targets more easily. Functional limitations tend to constraints a software project development manager's observations of a software problem. The principles are determined by decision makers (sector expert software top manager, academics) and literature; the criteria are as follows:

-Software Project Development Team Leadership

-Software Project Development Sectoral Expertise

- Personal and Software Project Development Environmental Analysis Capability

-Software Training and Education.

Software Project Development Team Leadership: The main objective of Software Project development Leadership is very essential for the success of Software Project Development of Lean Six Sigma software project development applications. Lean Six Sigma Software Manager (LSSSM) needs to be involved the software developers, and to increase their motivation.

Software Project Development Sectoral Expertise: The concept of this principle is very important technical skill to understand the software project development processes of the software Industry and software sub-division. The software project development manager can see the inputs and outputs of the software system easily, and have the identification, if he or she has a software project development sectoral expertise. Software project developers have only knowledge of the statistics and six sigma methodology; therefore, they cannot understand the software [project development problems of real world.

Personal and Software Project Development Environmental Analysis Capability: the main concept of this criteria is important to build a mathematical model to solve the technical problem by using analytical skill.

Software Training and Education: If the software project development manager knows statistical methods, lean six sigma concepts from reputed university degree or education, he/she can know why/how it is very much necessary these methods are. Since, sometime we contact software project development lean six sigma experts, even software project development professionals

- That they can solve a software project development problem and lean six sigma software problem

- They do not know the knowledge behind six sigma.

- If the model of the problem is somewhat different, they cannot solve the problem correctly. Software Industrial engineers or industrial and software system engineers may have an advantage for the title of lean six sigma software project development manager, because they learn statistics concentrated lean six sigma and give more importance to TQM (Total Quality Management), in addition, how a software service system or software project development system works at their universities.

\subsection{FUZZY ANALYTICAL HIERARCHY PROCESS} (FAHP)

Zadeh in the year of 1965 , he was the first person to introduced Fuzzy set theory. Important contribution of fuzzy set theory is its capability of representing indefinite information. The fuzzy set theory allows software programming and mathematical operators to apply to the fuzzy area. This fuzzy sets can convert a human's experience and judgment to quantitative and qualitative data. Commonly used techniques for MCDM (Multi Criteria Decision Making) is AHP (Analytic Hierarchy Process); in this, the most appropriate changes are found for a problem definition. Standard Analytical Hierarchical Process is an individual technique and form unbalanced measurement fuzzy scale. FAHP is used more frequently, since it can reflect human thinking style, whereas classical AHP cannot reflect. Fuzzy AHP can be used to prevent this risk. Concluded that "In software Industry, Pessimistic software project developers may not give any point more than four, or very optimistic people may easily give 5 even if it does not deserve it. These situations generate fuzziness within the decision making process, so fuzzy AHP method can handle these deviations concerning this fuzziness. Therefore, for the employee selection problems, if a multi-criteria decision making method with linguistic evaluations is selected, this method can be fuzzy AHP or similar methods concerning fuzzy conditions." fuzzy Analytic Hierarchy Process methodology is applied to the problem of the industrial manager selection of lean six sigma. 


\section{DEVELOPED FRAMEWORK AND AN INDUSTRIAL CASE STUDY APPLIED IN SOFTWARE COMPANY}

Software project Development Company is one of the most important sectors for employment all over the world. India's advantageous geographical location that stretches from Asia to Europe and Russia to Africa, allows it to be a hub. India's current Software Project Development Organization capacity is estimated to be $80-100$ billion US Doller and is evaluation to reach $108-140$ billion US Doller by 2021 . A very powerful and expanded economy will contribute to the expansion of the software Project Development Company. Because many Software companies support or rely on the software project development companies, their growth would indirectly stimulate growth in software project development. Global software project developers are keen to invest in India Since growth potential within the India's economy and its proximity to Europe and Asia. India has already attracted big global Software Professionals. The Lean Six Sigma Software Manager Software Developers Identification Flow Chart is shown in Figure 1

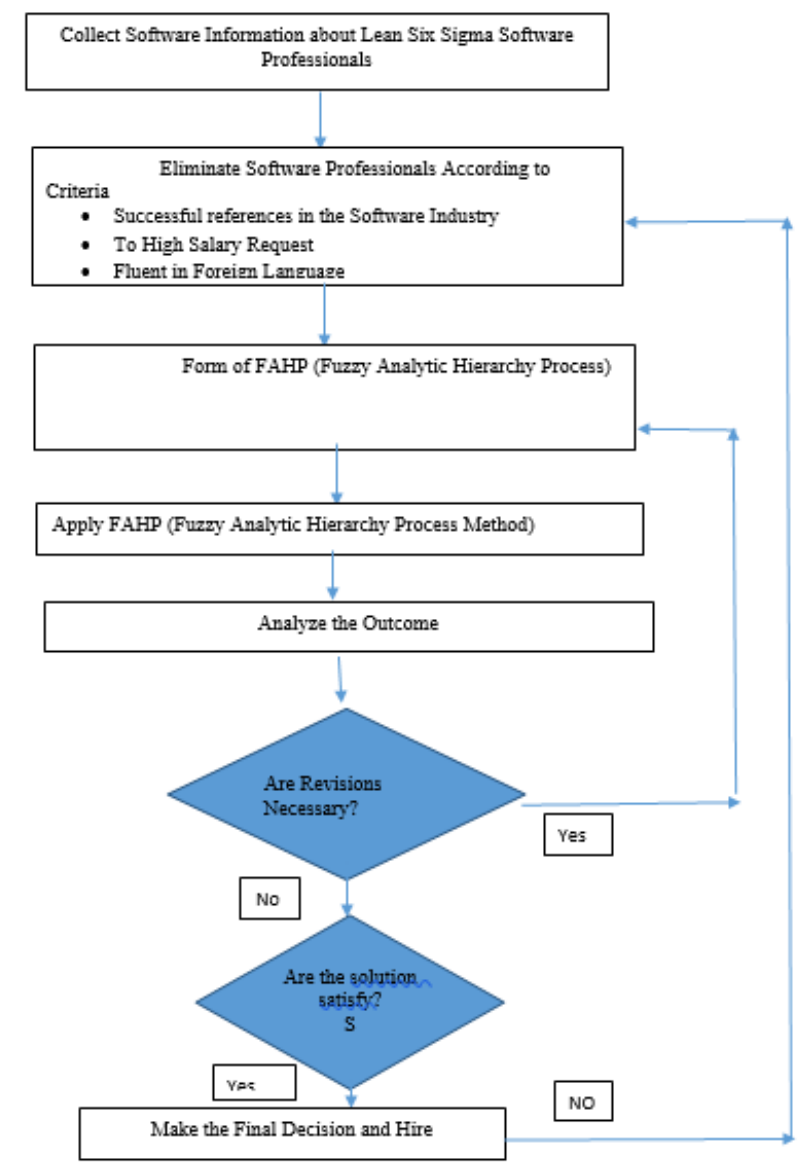

Figure 1. Lean Six Sigma Selection of Software Manager among Software Professionals

SOFTWARE PROJECT DEVELOPMENT COMPANY: India has a population of 138 crores people and is growing with rising income levels. This makes India's one of the largest software markets in its region, and the changing software consumer behavior of the new generation encourage domestic depletion. Software Companies are constantly observing for the present situation to improve their software project development performance and stay in software competitive markets. Software industries are visited and studied their software development processes carefully. Software industry visited, expert about logistics software are visited and analyzed their software. Information about the Software Company:

- To minimize times of the software customer orders,

- To minimize mean expenditure per order,

- To maximize software customer satisfaction,

- To maximize software project developers involvement and fulfilment,

- To minimize software project development quality problems,

- To minimize software project development customer grievances

Definition 1: A trapezoidal interval fuzzy set can be illustrated as below:

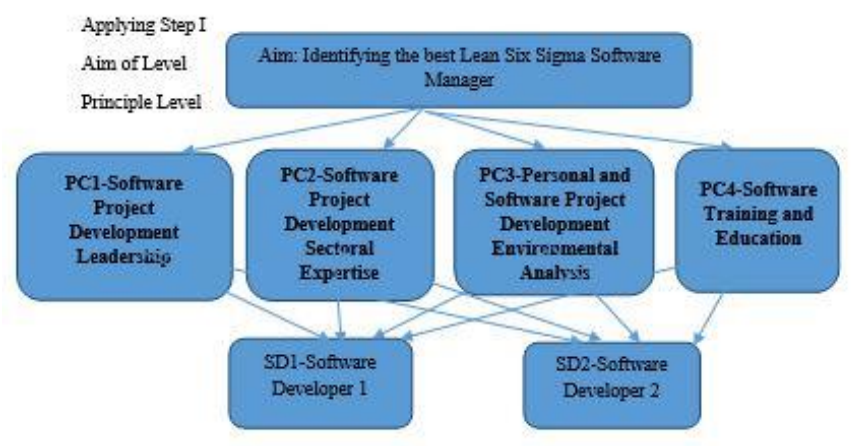

Figure 2. Hierarchy Structure

Definition 1: A Geometric structure trapezoidal interval fuzzy set:

Step 1: Structure the decision-making problem as a priority as the first step in the crisp Fuzzy Analytical Hierarchy process methodology. Further target has been set, standard level should be built. There might be sub-standard or subsubstandard level as well, which should be built one level below every time. The last level should be built for the alternatives.

Step 2: This step is called prioritizing or weighting the principles, here all the principles are compared and a pairwise comparison matrix is constructed. Comparisons should be made under the consideration of the goal (i.e. While manager selection process, is sectoral experience more important or educational level?). A linguistic matrix can be constructed with the values as: AS, VS, FS, SS, EE (can be seen in table below). (If criteria $\mathrm{A}$ is very strong (VS) with respect to criteria $\mathrm{B}$, in the corresponding cell of the matrix will get a value of "VS". However, the cell corresponding to criteria B w.r.t criteria A will get a reciprocal element of "VS" (1/VS). (How to calculate those values will be shown in another step.) 


\begin{tabular}{|l|l|l|l|l|}
\hline & PC1 & PC2 & PC3 & PC4 \\
\hline PC1 & EE & $1 /$ SS & FS & VS \\
\hline PC2 & SS & EE & VS & AS \\
\hline PC3 & $1 /$ FS & $1 /$ VS & EE & SS \\
\hline PC4 & $1 /$ VS & $1 /$ AS & $1 /$ SS & EE \\
\hline
\end{tabular}

Step 3: With the same logic from criteria comparison matrix described in step 2, alternative comparison matrices will be constructed under the consideration of each criterion (There will be 4 matrices if there are 4 criteria).

Applying Step 3: Alternative Matrix 1 (in relation with principle1)

\begin{tabular}{|l|l|l|}
\hline PC1 & A1 & A2 \\
\hline A1 & EE & 1/FS \\
\hline A2 & FS & EE \\
\hline
\end{tabular}

Alternative Matrix 2 (in relation with Principle2)

\begin{tabular}{|l|l|l|}
\hline PC2 & A1 & A2 \\
\hline A1 & EE & SS \\
\hline A2 & 1/SS & EE \\
\hline
\end{tabular}

Alternative Matrix 3 (in relation with Principle3)

\begin{tabular}{|l|l|l|}
\hline PC3 & A1 & A2 \\
\hline A1 & EE & AS \\
\hline A2 & 1/AS & EE \\
\hline
\end{tabular}

Alternative Matrix 4 (in relation with Principle4)

\begin{tabular}{|l|l|l|}
\hline PC4 & A1 & A2 \\
\hline A1 & EE & 1/VS \\
\hline A2 & VS & EE \\
\hline
\end{tabular}

Step 4: Linguistic comparison matrices should be converted to trapezoidal interval fuzzy sets' numerical values as it is shown below.

Definition 2:

AS Absolutely Strong (7.000,8.000,9.000,9.000;1.000,1.000) $(7.200,8.200,8.800,9.000 ; 0.800,0.800)$
VS Very Strong (5.000,6.000,8.000,9.000;1.000,1.000) (5.200,6.200,7.800,8.800;0.800,0.800)

FS Fairly Strong (3.000,4.000,6.000,7.000;1.000,1.000) $(3.200,4.200,5.800,6.800 ; 0.800,0.800)$

SS Slightly Strong $(1.000,2.000,4.000,5.000 ; 1.000,1.000)$ $(1.200,2.200,3.800,4.800 ; 0.800,0.800)$

EE Exactly Equal $(1.000,1.000,1.000,1.000 ; 1.000,1.000)$ $(1.000,1.000,1.000,1.000 ; 1.000,1.000)$

Cells with the reciprocal elements will be calculated

Definition 3: fuzzy sets let us model and minimize the effects of uncertainties in rule-base fuzzy logic systems.

Applying

Step 4:

Table 1. Criteria Comparison Matrix

\begin{tabular}{|c|c|c|c|c|}
\hline & PC1 & $\mathrm{PC} 2$ & PC3 & PC4 \\
\hline PC1 & $\begin{array}{l}{[1.000,1.00} \\
0,1.000,1.0 \\
00 ; 1.000,1 . \\
000][1.000, \\
1.000,1.00 \\
0,1.000 ; 1.0 \\
00,1.000]\end{array}$ & $\begin{array}{l}.2, .25, .5,1 \\
; 1,1] \\
\\
{[.208, .263,} \\
.454, .833 ; \\
8, .8]\end{array}$ & $\begin{array}{l}{[3,4,6,7 ; 1,} \\
1] \\
{[3.2,4.2,5.8} \\
, 6.8 ; .8, .8]\end{array}$ & $\begin{array}{l}{[5,6,8,9 ; 1} \\
1] \\
{[5.2,6.2,7} \\
.8,8.8 ; .8, . \\
8]\end{array}$ \\
\hline PC2 & $\begin{array}{l}{[.200, .250, .} \\
5.000,1.00 \\
0 ; 1.000,1.0 \\
00] \\
{[.208, .263, .} \\
454, .833 ; .8 \\
.000, .8 .000 \\
]\end{array}$ & $\begin{array}{l}{[1,1,1,1 ; 1,} \\
1][1,1,1,1 ; \\
1,1]\end{array}$ & $\begin{array}{l}{[5,6,8,9 ; 1,} \\
1] \\
{[5.2,6.2,7.8} \\
, 8.8 ; 8,8,8]\end{array}$ & $\begin{array}{l}{[7,8,9,9 ; 1} \\
, 1][7.2,8 . \\
2,8.8,9 ; .8 \\
, .8]\end{array}$ \\
\hline PC3 & $\begin{array}{l}{[.142, .166, .} \\
25, .33 ; 1,1][ \\
.147, .172, . \\
238, .312 ; .8 \\
, .8]\end{array}$ & $\begin{array}{l}.11, .125, . \\
166.2 ; 1,1][ \\
.11, .113, .1 \\
21, .138 ; .8, . \\
8]\end{array}$ & $\begin{array}{l}{[1,1,1,1 ; 1,} \\
1][1,1,1,1 ; \\
1,1]\end{array}$ & $\begin{array}{l}{[1,2,4,5 ; 1} \\
, 1][1.2,2 . \\
2,3.8,4.8 ; \\
.8,8]\end{array}$ \\
\hline PC4 & $\begin{array}{l}{[.11, .125, .1} \\
66.2 ; 1,1][.1 \\
1, .113, .121 \\
.138 ; .8, .8]\end{array}$ & $\begin{array}{l}{[.11, .11, .1} \\
25, .142 ; 1,1 \\
][.11, .113, . \\
121, .138 ; .8 \\
, .8]\end{array}$ & $\begin{array}{l}{[.2, .25, .5,1,} \\
; 1,1] \\
{[.208, .263, .} \\
454, .833 ; .8 \\
, .8]\end{array}$ & $\begin{array}{l}{[1,1,1,1 ; 1} \\
, 1][1,1,1, \\
1 ; 1,1]\end{array}$ \\
\hline
\end{tabular}

Step 5: The consistency check:

Step 5.1: The consistency should be checked for each pairwise comparison matrices. In order to do that, Defuzzified Trapezoidal Fuzzy Set (DTFS) approach, in defuzzification, will be used.

Definition 4:

After applying the equation above for every fuzzy number, there will be crisp numbered comparison matrices(C).Those matrices will be used in order to find the consistency ratios applying Step 5.1: 
After applying DTFS method for every fuzzy number in the criteria comparison matrix, we will get a new matrix as seen below.

\begin{tabular}{|l|c|c|c|c|}
\hline & PC1 & PC2 & PC3 & PC4 \\
\hline PC1 & 1,00 & 0,45 & 4,75 & 6,65 \\
\hline PC2 & 2,85 & 1,00 & 6,65 & 7,85 \\
\hline PC3 & 0,21 & 0,14 & 1,00 & 2,85 \\
\hline PC4 & 0,14 & 0,12 & 0,45 & 1,00 \\
\hline
\end{tabular}

Alternative matrices do not need a consistency check, since $\mathrm{n}=2, \mathrm{RI}=0$ which means the matrix is already consistent.

Step 5.2: By eigenvector method used in all comparison matrices, the crisp priority weights will be calculated. The eigenvector method is formulated below: The columns of given matrix are summed. Every value in a column will be divided by the calculated column's sum. This is made to normalize the crisp values.

Applying Step 5.2: Every cell value is divided by the sum of the cells in each column.

\begin{tabular}{|l|c|c|c|c|}
\hline & PC1 & PC2 & PC3 & PC4 \\
\hline PC1 & 0,24 & 0,26 & 0,37 & 0,36 \\
\hline PC2 & 0,68 & 0,59 & 0,52 & 0,43 \\
\hline PC3 & 0,05 & 0,08 & 0,08 & 0,16 \\
\hline PC4 & 0,03 & 0,07 & 0,03 & 0,05 \\
\hline
\end{tabular}

Step 5.2: From the new matrix, each row's average values will be calculated and will be written as the weight array (W).

Applying Step 5.2

$$
\left(\begin{array}{l}
W 1 \\
W 2 \\
W 3 \\
W 4
\end{array}\right)=\left(\begin{array}{l}
0,31 \\
0,55 \\
0,09 \\
0,05
\end{array}\right)
$$

Weight array will show the importance of the criteria as $\mathrm{C} 1$ has an importance of $31 \%, \mathrm{C} 2$ has $55 \%, \mathrm{C} 3$ has $9 \%$ and $\mathrm{C} 4$ has $5 \%$ of importance. It can be derived from this result that personal and environmental analysis ability (C2) is the most important criteria among all; leadership property (C1) is more important than sectoral knowledge (C3) and problem solving property (C4). Sectoral knowledge (C3) and problem solving property (C4) are very close in importance but sectoral knowledge is a more appreciated property in this case.

Step 5.2: The firstly calculated crisp comparison matrices (C) will be multiplied with their corresponding weight arrays. A new array of $\mathrm{C}^{*} \mathrm{~W}$ will be obtained.

Applying Step 5.2: $\left(\begin{array}{l}a 11 * w 1+a 12 * w 2+a 13 * w 3+a 14 * w 4 \\ a 21 * w 1+a 22 * w 2+a 23 * w 3+a 24 * w 4 \\ a 31 * w 1+a 32 * w 2+a 33 * w 3+a 34 * w 4 \\ a 41 * w 1+a 42 * w 2+a 43 * w 3+a 44 * w 4\end{array}\right)=\left(\begin{array}{c}1,3 \\ 2,4 \\ 0,4 \\ 0,2\end{array}\right)$

Step 5.2: CW array will be divided by the weight $\operatorname{array}(\mathrm{W})$ by using matrix division. The resulted array is (Eigenvectors will be calculated for each matrix separately.) eigenvector $(\mathrm{W} i=[\lambda 1, \lambda 2 \ldots])$ of the corresponding matrix.

Table 2. Global Weight

\begin{tabular}{|l|l|l|l|}
\hline \multicolumn{2}{|c|}{ Fuzzy Global Weights } & $\begin{array}{l}\text { Defuzzified } \\
\text { Weights }\end{array}$ & $\begin{array}{l}\text { Normalized } \\
\text { Weights } \\
\text { (Crisp } \\
\text { Values) }\end{array}$ \\
\hline SD & $\begin{array}{l}(0.88,0.257,0.878,0.65 \\
8 ; 1,1) \\
(0.171,0.371,0.862,0.5 \\
88 ; 0.8,0.8)\end{array}$ & 0.615 & 0.23 \\
\hline SD & $\begin{array}{l}(0.226,0.437,0.648,3.6 \\
21 ; 1,1) \\
2\end{array}$ & $\begin{array}{l}2.083 \\
(0.363,0.428,0.602,2.2 \\
21 ; 0.8,0.8)\end{array}$ & \\
& & & \\
\hline
\end{tabular}

From the case results given above table, it can be seen that in the given comparisons, Software Development manager SD2 is a far better choice with a 0,23 points comparing to the Lean Six Sigma Software Development Manager SD1 with a 0,77 points.

\section{CONCLUSIONS}

The decision makers meet different software factors when deciding to identify the most suitable lean six sigma software project development manager. If a not suitable software manager is identified, the wrong decision may spoil the success of lean six sigma software projects and the inspiration and ethical of the related software project development team members in the software Industry. Software experts and academics believe that the process of personnel identification should be on justice and with minimum subjectivity. Manager, project management and six sigma techniques used for the selected problem are very important for the success of six sigma projects. This paper focuses the personnel selection topic for lean six sigma, because improper software manager may focus wrong priorities and cannot use the right techniques. The selection of the lean six sigma software manager may be a different one under the different situations. The originality of the paper is using fuzzy logic multi criteria decision making to select the best lean six sigma candidate software manager. In addition, some criteria are defined to eliminate improper candidates such as "Successful References in the Sector", "Too high salary request" and "Fluent in 
foreign language" before the application of Multi Criteria Decision Making technique. Since the problem of selection of lean six sigma software manager has various and conflicting software criteria, it is a Multi Criteria Decision Making problem. Fuzzy Analytical Hierarchical Process is used very commonly, because it can reflect human thinking style, whereas classical Analytical Hierarchical Processes cannot reflect properly. The trapezoidal interval fuzzy logic Analytic Hierarchy Process methodology, which is one of the most used methods, is applied for an industrial software manager selection. The membership functions of fuzzy logic sets are crisp; therefore, they cannot model uncertainties directly. Nevertheless, the membership functions of fuzzy logic sets, they can model uncertainties. The framework of the study is:

- Collect Information about the Candidates of Lean Six Sigma software Manager position,

- Eliminate improper Candidates according to the defined criteria,

- Form FAHP Technique

- Apply FAHP Technique

- Make the Final Decision After the evaluations of decision makers and a literature review, 4 criteria are used. Some candidates are eliminated according to the rules defined in the approach, then 2 candidates are compared. Interval fuzzy logic sets represent uncertainties, better. Firms can use the methodology when attempting to select both lean six sigma software managers and other managers. The lessons learnt from this logistics firm case or other applications can be added into the knowledgebase of a decision support system. As further research, some sensitivity analysis can be done and other Multi Criteria Decision Making Techniques can be applied and their performances can be compared.

\section{REFERENCES}

[1] Chandrakanth G Pujari and Dr.Seetharam K., "An Evaluation of Effectiveness of the

Software Projects Developed Through Six Sigma Methodology", American Journal of

Mathematical and Management Sciences, 34(1) • January 2015-16

[2] Buglione, L., Trudel, S. (2010), "Guideline for sizing Agile

projects with COSMIC",

In: Proceedings of the IWSM / MetriKon / Mensura 2010, Stuttgart, Germany

[3] Bhasin, S. (2011), "Performance of organizations treating lean as an ideology", Business

Process Management Journal, Vol. 17 No. 6, pp. 986-1011.

[4] Bergmiller, G.G. and McCright, P.R. (2009), "Parallel models

for lean and green

operations", paper presented at Industrial Engineering Research Conference, Miami, FL.

[5]Furlan, A., Vinelli, A. and Dal Pont, G. (2011), "Complementary and lean manufacturing

bundles: an empirical analysis", International Journal of

Operations \& Production

Management, Vol. 31 No. 8, pp. 835-850.

[6] George, M. ed. (2010), "The Lean Six Sigma Guide to Doing

More with Less cost", John

Wiley \& Sons, Hoboken, NJ

[7] Stone, K.B. (2012), "Four decades of lean: a systematic

literature review", International

Journal of Lean Six Sigma, Vol. 3 No. 2, pp. 112-132.

[8]Vinodh, S. and Balaji, S. (2011), "Fuzzy logic based Leanness assessment and its decision

support system", International Journal of Production Research, Vol. 49 , pp. $40-67$
[9]Zhang, Q., bbas, J., Zhu, X. and Shah, M. (2012), "Critical success factors for successful

Lean Six Sigma implementation in Pakistan”, Interdisciplinary Journal of Contemporary

Research in Business, Vol. 4 No. 1, pp. 117-124.

[10]S.M. Kazemi, (16-18 July 2012). Six Sigma project selection by using a fuzzy

Multiple criteria decision-making approach a case study in poly acryl corp. CIE42 proceedings, Cape Town, South Africa 2012 CIE \& SAIIE.

[11]Snee, Ronald: Leading Six Sigma: A Step-by-Step Guide Based on Experience with

GE and Other Six Sigma Companies, Financial Times Prentice Hall 2002

[12] Stone, K.B. (2012), "Four decades of lean: a systematic literature review", international Journal of Lean Six Sigma, Vol. 3 No. 2, pp. 112-132.

[13] Vinodh, S. and Balaji, S. (2011), "Fuzzy logic based Leanness assessment and its

decision support system", International Journal of Production Research, Vol. 49, pp.

40-67.

[14] Furlan, A., Vinelli, A. and Dal Pont, G. (2011), "Complementary and lean

manufacturing bundles: an empirical analysis", International Journal of Operations \&

Production Management, Vol. 31 No. 8, pp. 835-850.

[15]Maroofi, F. and Dehghan, S. (2012), "Performing lean manufacturing system in small

and medium enterprises", International Journal of Academic Research in Accounting,

Finance and Management Sciences, Vol. 2 No. 3 pp. 156-163.

[16] Nordin, N., Deros, B.M. and AbdWahab, D. (2012), "A framework for managing

change in lean manufacturing implementation", International Journal of Services and

Operations Management, Vol. 12 No. 1, pp. 101-117.

[17]Stone, K.B. (2012), "Four decades of lean: a systematic literature review", International Journal of Lean Six Sigma, Vol. 3 No. 2, pp. 112-132.

[18] Chandrakanth G Pujari and Dr. Seetharam K.," Top Priority of Software Success Factor for Six Sigma Execution by a Fuzzy Hierarchical Process", International Journal of Multimedia and Ubiquitous Engineering 9 (11), 171-180, 2014-15

[19] Chandrakanth G Pujari and Dr. SeetharamK.,"Evaluation for Defective Density in All the Right Places", Indian journal of engineering, 2014, 11(26), 30-37

[20]Chandrakanth G Pujari and Dr.SeetharamK."Ranking of Tools use, software logical complexity, Requirement volatility, Quality requirements, Efficiency requirements in software development", 2009 IEEE International Advance Computing Conference, DOI: 10.1109/IADCC.2009.4809258, Date Added to IEEE Xplore: 31 March 2009

[21]Chandrakanth G Pujari, "Software Information Flexibility for Lean Six sigma Software Development Using Multiple Regression Analysis”, Indian Journal of Engineering, 2017, 14(36), 95-107 [22]Chandrakanth G Pujari,Dr.SeetharamK,"'Investigating the Effects of Factors on Software Development", International Journal of Computer Applications, vol. 1, issue 6, pp. 56-65, February 2010, 10.5120/142-261

[23] Chandrakanth G Pujari and Dr. SeetharamK.,Article:

"Estimation of Growth Parameters for a Software

Development". International Journal of Computer

Applications 35(12):38-42, December 2011.

[24]Chandrakanth G Pujari, Kavyashree N, Dr.Supriya M

C'Enhancement of Indian Software Quality Management Using Multi Criteria Objects and Six Sigma Methodology",

International Journal on Future Revolution in Computer Science \& Communication Engineering ISSN: 2454-4248 Volume: 4 Issue: 4 $806-812019$

[25] Chandrakanth G Pujari, Dr. SeetharamK, "Detection and 
valuation of major error trends of software projects using pareto principle and fuzzy model", National journal on advances in computing \& Management, vol 3 no. 2 october 2012.

[26]Chandrakanth G Pujari, Kavyashree N, Dr.Supriya M C, "Development of a Methodology for Software Small and Medium Scale Industries in the Selection of Suitable Lean Six Sigma Tools", JASC: Journal of Applied Science and Computations Volume VI, Issue II, February/2019 ISSN NO: 1076-5131

[27]Chandrakanth G Pujari and Dr.Seetharam K, "Software Defects Identification Using Principles of Data Gathering and Pareto Analysis",DOI: 10.5176/2251-2217_SEA12.36, 2012

[28]Chandrakanth G Pujari and Dr.Seetharam K," Software Defects Identification Using Principles of Data Gathering and Pareto Analysis", DOI: 10.5176/2251-2217_SEA12.36 2012

[29]Chandrakanth G Pujari , "Modeling Software Project

Defects With Fuzzy Logic Maps", International Journal on Future

Revolution in Computer Science \& Communication Engineering ISSN: 2454-4248 Volume: 4 Issue: 4103 - 107, IJFRCSCE | April 2018, Available @ http://www.ijfrcsce.org

[30]Chandrakanth G Pujari and Dr. Seetharam K,"

Implementation of Multivariate Clustering Methods for

Software Development", https://www.bvicam.ac.in 